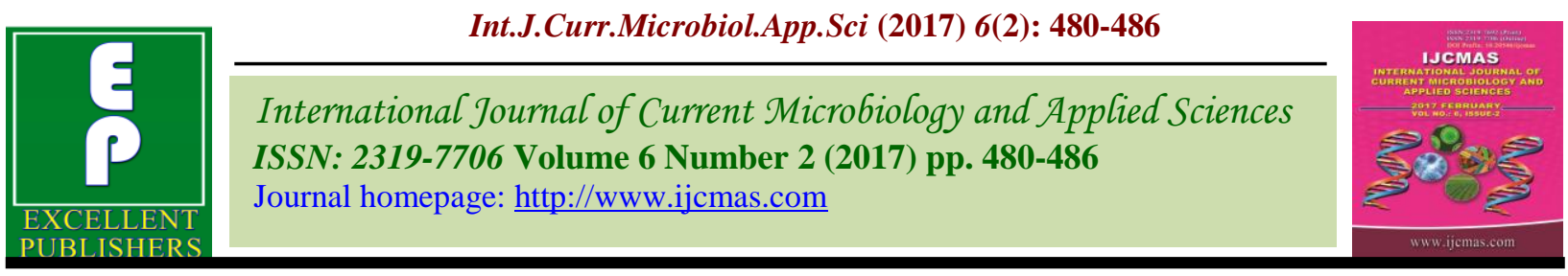

Original Research Article

http://dx.doi.org/10.20546/ijcmas.2017.602.054

\title{
Economic Analysis of Feeding Management and Milk Production at the University Dairy Farm
}

\author{
Mayank Dubey, Vivek Pratap Singh*, R.K. Pandey and A.K. Chaubey \\ Department of Animal Husbandry and Dairying, Institute of Agricultural Sciences \\ Banaras Hindu University, Varanasi-221005, India \\ *Corresponding author
}

\begin{tabular}{|c|c|}
\hline & A B S T R A C T \\
\hline Keywords & \multirow{4}{*}{$\begin{array}{l}\text { A study was conducted at the Banaras Hindu University Dairy Farm to estimate } \\
\text { the effects of feeding management practices on rearing of animals and milk } \\
\text { production in terms of economic analysis. The data pertaining to the feeds and } \\
\text { feeding systems being followed and their input costs were collected from the } \\
\text { records maintained for all the animals at the dairy farm. The lactation yield of } \\
\text { cows and buffaloes has been worked out to } 996 \text { and } 1150 \text { Litres, respectively. The } \\
\text { cost of daily feeding per head and per Litre of milk has been estimated to Rs. } \\
60.26 \text { and Rs. } 10.80 \text {, respectively. Consequently, the cost of milk production could } \\
\text { be reduced substantially by following the package of practices adopted for } \\
\text { breeding, feeding and management of dairy animals on scientific lines. }\end{array}$} \\
\hline $\begin{array}{l}\text { Breed, Milk } \\
\text { Production, } \\
\text { Feed, Cost. }\end{array}$ & \\
\hline Article Info & \\
\hline $\begin{array}{l}\text { Accepted: } \\
\text { 15 January } 2017 \\
\text { Available Online: } \\
\text { 10 February } 2017\end{array}$ & \\
\hline
\end{tabular}

\section{Introduction}

The livestock sector by contributing milk, eggs and meat to be food basket plays a critical role in fulfilling the animal protein requirement of the people. The per capita availability of milk is 281 gm (Statistics, NDDB, 2011-12). India posses the largest number of cattle population with 199.1 million and buffalo population 105.4 million and it is also world's leading milk producing country with $121.8 \mathrm{mt}$. (Annual Report 201112, DAHD \& F, MOA). Livestock sector contributed 5.3 per cent of total gross domestic product (GDP) while the share of livestock in whole agriculture is about 30 per cent. Contribution of livestock in national income is about 26 per cent (FAO statistical year Book, 2012). In spite of India's position as highest producer of milk but productivity per animal is very poor. Demand for milk over the time is very likely to increase due to growth in population, increased incomes and urbanization. It is, therefore necessary to meet the increasing demand of milk and its products from domestic sources.

Balance ration is one which supplies all the nutrients necessary to nourish the animal properly during twenty four hour period. It depends upon the animal breed type and purpose for which animal is kept, with a balance ration an animal can get the best out of all the constituent present in their food. If the cattle are not fed properly, they show deficiency symptoms such as retarded growth, 
poor production, delayed maturity and disturbance in reproduction efficiency. Thus a balance ration is more purposeful and beneficial. The knowledge of absolute and relative profitability for each type of breed becomes an important issue for rational decision making on the farm. Cost and returns of milk production vary among different types of milch animals and also among different breeds. It is of immense importance for the farmers to know the economics of the milk production.

\section{Materials and Methods}

For the present study Dairy farm, Institute of Agricultural Sciences, Banaras Hindu University (BHU), Varanasi, was under taken. The farm is situated in the University premises, which comes under the urban location. The B.H.U. Dairy Farm is research and educational farm where various categories of animals are kept.

The herd maintained on scientific lines of feeding and management practices to provide enhanced milk production with a view to become a role- model for the dairy farmers in this area. For this purpose the data pertaining to feeds, feeding management practices and milk production were collected. Data were analyzed and means \& percentages were determined for various economic traits and correlation coefficient (r) between the traits was calculated with the help of Pearson's formula of correlation coefficient:

$$
r=\frac{n \sum x y-\left(\sum x\right)\left(\sum y\right)}{\sqrt{n\left(\sum x^{2}\right)-\left(\sum x\right)^{2}} \sqrt{n\left(\sum y^{2}\right)-\left(\sum y\right)^{2}}}
$$

\section{Results and Discussion}

The herd statistics about the different categorizes of adult and young stocks maintained at the B.H.U. dairy farm, in which it is clear that the total number of adult females of all categories of breeds including the cross-bred were found to be 111.Similarly the number of young stocks of different agegroups were estimated as 122 females and 25 males. However, the number of adult males was also recorded as three (Table 1). The average number of milch animals throughout the year was 60.16, which includes the various breeds of cattle and buffaloes viz. Haryana, Sahiwal, Crossbred of Sahiwal X Holstein-Frisian (SXHF), Sahiwal X Jersey (SXJ), Haryana X Holstein-Frisian (HXHF), Hariyana X Jersey (HXJ) and Murrah buffaloes. The breed wise composition of the total milch animal has been worked out to $3.74 \%$ Haryana, $4.57 \%$ Sahiwal, $86.28 \%$ cross bred of all the categories and $5.40 \%$ buffaloes (Table 2).

\section{Milk production performance at the dairy farm}

The overall monthly average of milk production at the dairy farm was calculated as 10865.07 litres where as the wet average of milk for twelve months of financial year starting from April till March were estimated as 3.60, 3.89, 4.15,4.34, 6.18, 5.23, 7.59, 8.93, 7.74, 9.26, 7.72 and 6.58 respectively (Table 3 ). This clearly indicate that the milk production significantly increased from April to March $(\mathrm{P}>0.05)$. The average lactation yield, based on 300 days of lactation, for cows and buffaloes has been worked out to 996 and 1150 liters, which is greater than average annual yield of $157 \mathrm{~kg}$ for cows and $504 \mathrm{~kg}$ for buffalos in the country as a whole (Singh et al., 1986) (Fig. 1).

\section{Feeds and feeding management}

Feed cost is considered to be the major component of cost accounting for about 60 per cent of the gross cost of producing a litter 
of milk. Akturk et al., (2010), and Tatlidil (2002) reported that the highest proportion among the variable costs belongs to the feed $(71.34 \%)$ and labor $(19.47 \%)$ costs. In similar studies Turkyhlmaz \& Aral (2002) reported the proportion of the feed and labor costs are calculated as $62.43 \%$ and $16.43 \% ; 62.60 \%$ and $18.81 \%$ Canakkale and Aydin province. These results are much closer to our findings. Details of feeding cost per animal and per litters of milk was calculated separately monthly basis (Table 4). The cost of milk production for a litter of milk computed for the year April 2009 and March 2010 and the details are given in (Table 4). The annual feed cost for per milch animal estimated to Rs.19191.7. In which $11.00 \%$ of green fodder, $12.69 \%$ of dry roughages and $76.30 \%$ of concentrates which are close to the findings of Gupta (1988) i.e. 61.4 per cent in Muzaffarnagar district. The monthly variation in feed cost for milch animals per head per day have been worked out and it was found to be from months April to March Rs. 52.58, Rs. 53.89, Rs. 56.33, Rs. 58.23, Rs. 60.88, Rs. 63.68, Rs. 64.61, Rs. 63.64, Rs. 69.27, Rs. 70.62, Rs. 71.80 and Rs. 72.78, respectively. This clearly indicates that the feed cost is minimum in month of April and highest in March (Table 4). The share of average feed cost spent on green fodder, dry roughages and concentrates was also calculated and it was found Rs.6.95, Rs.8.02 and Rs.48.20 per head per day which is $11.00 \%, 12.69 \%$ and $76.30 \%$ respectively of total feed cost (Table 4). The relationship between the number of milch Animals and quantity of total feed consumed has been worked out and a significant $(\mathrm{P}>0.05)$ positive correlation were found $(\mathrm{r}=$ $0.5134 * *)$ similarly a highly significant $(\mathrm{P}>0.05)$ positive correlation coefficient observed between the number of milch animals and total feed cost $\left(r=0.6285^{* *}\right)$ (Table 4). Mean efficiency of the sample farmers is estimated to be around $78 \%$, ranging from $0.43-0.98$ indicating that there is significant scope for increasing efficiency under current technology. Results of the inefficiency analysis indicate that $96 \%$ of the variation in milk production is due to inefficiency. Efficiency levels are all affected in the expected direction by the selected determinants of the inefficiency model however, only cow quality variable was found to be statistically significant (Tuna Alemdar et al., 2010).

\section{Variation in feed cost for per litre of milk production}

The average cost spent on different feeds fed to milch animals, are estimated in which concentrate is the most costly item of the total feed cost as $76.30 \%$. However, mean total feed cost was Rs. 63.17 per head per day whereas, mean of total feed cost was 10.88 per day per litre milk production. The share of different feed items for per litre of milk production was also calculated and it was found to be Rs. 1.22 for green fodder, Rs. 1.44 for dry roughages and Rs. 8.21 for concentrates per litre of milk production accounting $11.22 \%, 13.24 \%$ and $75.52 \%$ respectively, for per litre of milk production (Table 4).

The result associated with Sainz-Sanchez et al., (2017) who reported that the higher supplementation with commercial concentrate resulted in higher feeding costs with no advantage in terms of milk yield, so that treatments with low supplementation resulted in higher margins over costs. This shows that the concentrate is the most costly item in the total feed cost and this is served in sufficient amount to the milch animals on scientific grounds. 
Table.1 Breed-wise details of herd statistics of cattle and buffalo species at the dairy farm

\begin{tabular}{clccccc}
\hline S. & Breed & $\begin{array}{c}\text { Number of } \\
\text { Adults }\end{array}$ & \multicolumn{2}{c}{$\begin{array}{c}\text { Number of Young- } \\
\text { stocks }\end{array}$} & $\begin{array}{c}\text { Number of } \\
\text { Adult Males }\end{array}$ & Total \\
\cline { 3 - 4 } & & Females & Female & Male & & \\
\hline 1. & Haryana & 5 & 11 & 3 & - & 19 \\
2. & Sahiwal & 5 & 9 & 3 & 1 & 18 \\
3. & Cross Bred & 93 & 97 & 12 & 1 & 203 \\
4. & Murrah & 8 & 5 & 7 & 1 & 21 \\
& Total & 111 & 122 & 25 & 3 & 261 \\
\hline
\end{tabular}

Table.2 the details of milking cow and buffalo breeds during different months in the session 2009-2010 at the dairy farm

\begin{tabular}{clccccc}
\hline $\begin{array}{c}\text { S. } \\
\text { No. }\end{array}$ & Months & Sahiwal & Harayana & Cross Bred & Murrah & Total \\
\hline 1 & April & 4 & 6 & 63 & 4 & 77 \\
2 & May & 4 & 5 & 59 & 4 & 72 \\
3 & June & 4 & 3 & 60 & 3 & 70 \\
4 & July & 4 & 3 & 61 & 3 & 71 \\
5 & August & 4 & 3 & 43 & 3 & 53 \\
6 & September & 3 & 2 & 55 & 4 & 64 \\
7 & October & 2 & 1 & 39 & 4 & 46 \\
8 & November & 2 & 1 & 36 & 3 & 42 \\
9 & December & 2 & 1 & 40 & 2 & 45 \\
10 & January & 1 & 1 & 44 & 2 & 48 \\
11 & February & 1 & 3 & 57 & 3 & 64 \\
12 & March & 4 & 3 & 60 & 3 & 70 \\
\hline
\end{tabular}

Fig.1 Buffalo and cow milk production on different months

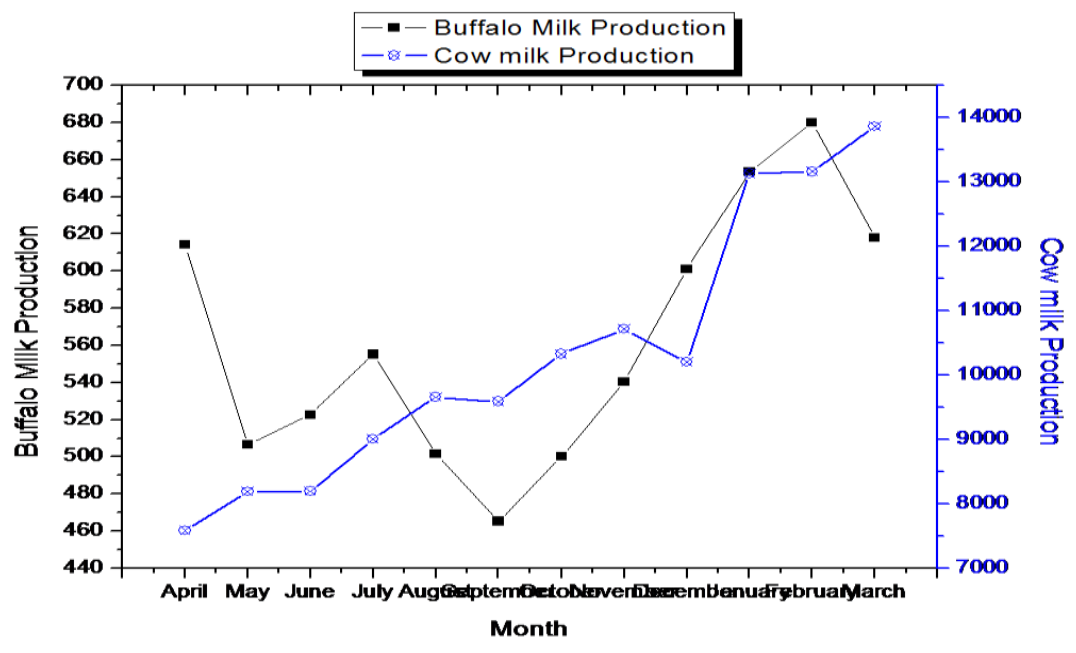


Table.3 Details about the monthly milking females and milk production performance at the dairy farm

\begin{tabular}{|c|c|c|c|c|c|c|c|c|c|}
\hline \multirow{2}{*}{$\begin{array}{c}\text { S. } \\
\text { No. }\end{array}$} & \multirow[t]{2}{*}{ Months } & \multicolumn{3}{|c|}{ Cow } & \multicolumn{3}{|c|}{ Buffalo } & \multirow[b]{2}{*}{$\begin{array}{c}\text { Total milk } \\
\text { production } \\
\text { both cows } \\
\text { and } \\
\text { buffaloes in } \\
\text { litre }\end{array}$} & \multirow[b]{2}{*}{$\begin{array}{c}\text { Average } \\
\text { milk } \\
\text { production } \\
\text { per head for } \\
\text { both cow } \\
\text { and } \\
\text { buffaloes } \\
\text { (Litres) } \\
\end{array}$} \\
\hline & & $\begin{array}{c}\text { No of } \\
\text { milking } \\
\text { females }\end{array}$ & $\begin{array}{c}\text { Amount of } \\
\text { milk } \\
\text { production } \\
\text { of cows } \\
\text { (Litres) }\end{array}$ & $\begin{array}{c}\text { Average } \\
\text { milk } \\
\text { production } \\
\text { of cows } \\
\text { (Litres) }\end{array}$ & $\begin{array}{l}\text { No of } \\
\text { milking } \\
\text { females }\end{array}$ & $\begin{array}{l}\text { Amount of } \\
\text { milk } \\
\text { production } \\
\text { of buffaloes } \\
\text { (Litres) }\end{array}$ & $\begin{array}{c}\text { Average } \\
\text { milk } \\
\text { production } \\
\text { of buffaloes } \\
\text { (Litres) }\end{array}$ & & \\
\hline 1. & April & 73 & 7586.2 & 3.46 & 4 & 614.2 & 5.11 & 8200.4 & 3.60 \\
\hline 2. & May & 68 & 8187.8 & 3.88 & 4 & 506.4 & 4.08 & 8694.2 & 3.89 \\
\hline 3. & June & 67 & 8195.2 & 4.07 & 3 & 522.6 & 5.80 & 8717.8 & 4.15 \\
\hline 4. & July & 68 & 9004.4 & 4.41 & 3 & 555.2 & 5.96 & 9559.6 & 4.34 \\
\hline 5. & August & 50 & 9658.2 & 6.23 & 3 & 501.4 & 5.38 & 10159.6 & 6.18 \\
\hline 6. & September & 60 & 9588.0 & 5.32 & 4 & 465.2 & 3.87 & 10053.2 & 5.23 \\
\hline 7. & October & 42 & 10325.0 & 7.93 & 4 & 500.2 & 4.03 & 10825.2 & 7.59 \\
\hline 8. & November & 39 & 10715.4 & 9.15 & 3 & 540.4 & 6.00 & 11255.8 & 8.93 \\
\hline 9. & December & 43 & 10205.2 & 7.65 & 2 & 601.2 & 9.69 & 10806.4 & 7.74 \\
\hline 10. & January & 46 & 13131.4 & 9.20 & 2 & 653.4 & 10.53 & 13784.8 & 9.26 \\
\hline 11. & February & 61 & 13160.8 & 7.70 & 3 & 680.0 & 8.10 & 13840.8 & 7.72 \\
\hline 12. & March & 67 & 13865.0 & 6.67 & 3 & 618.0 & 6.64 & 14483.0 & 6.58 \\
\hline & Total & 684 & 123622.6 & & 38 & 6758.2 & & 130380.8 & \\
\hline
\end{tabular}

Fig.2 Total feed cost variation

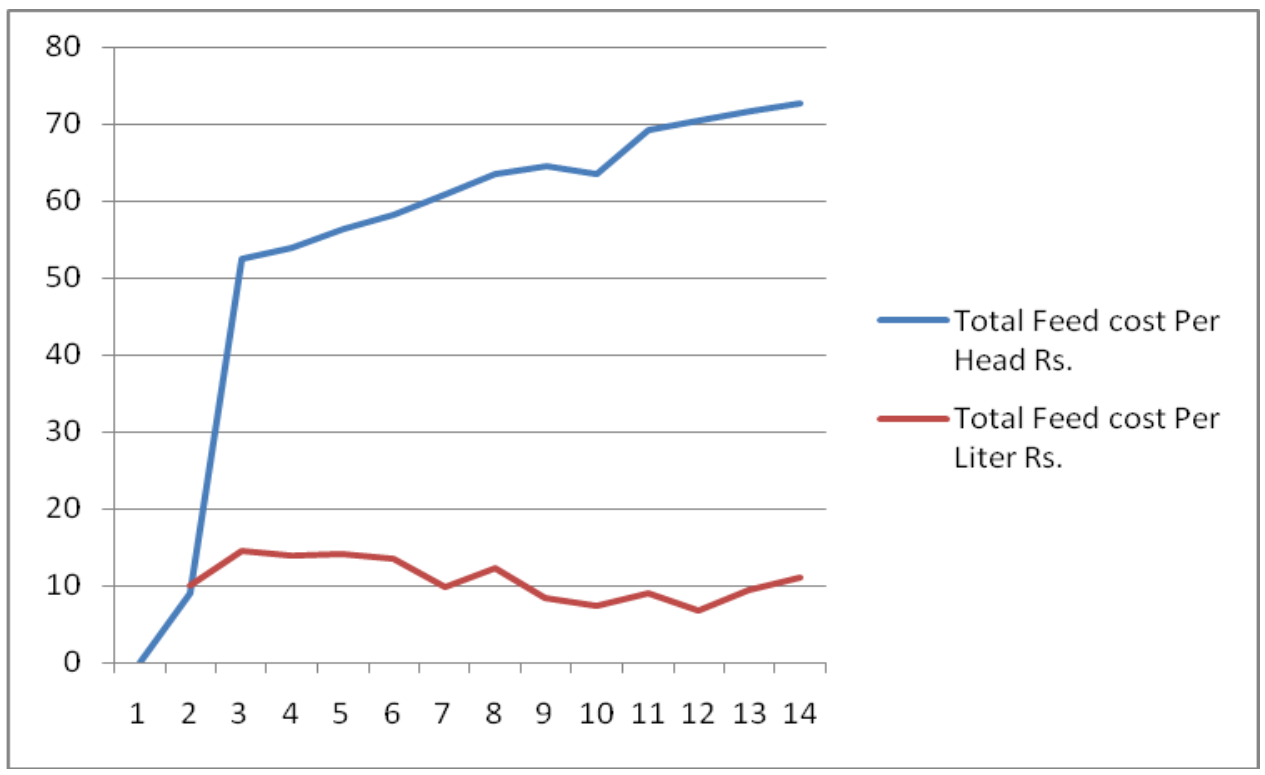


Table.4 Variations in expenditure incurred to feeding milch animals at the dairy farm

\begin{tabular}{|c|c|c|c|c|c|c|c|c|c|}
\hline \multirow{2}{*}{$\begin{array}{c}\text { S. } \\
\text { No. }\end{array}$} & \multirow[t]{2}{*}{ Months } & \multicolumn{2}{|c|}{ Green fodder } & \multicolumn{2}{|c|}{ Dry Roughages } & \multicolumn{2}{|c|}{ Concentrates } & \multicolumn{2}{|c|}{ Total Feed cost } \\
\hline & & $\begin{array}{l}\text { Per Head } \\
\text { (Rs.) }\end{array}$ & $\begin{array}{l}\text { Per Liter } \\
\text { (Rs.) }\end{array}$ & $\begin{array}{c}\text { Per head } \\
\text { (Rs.) }\end{array}$ & $\begin{array}{c}\text { Per Liter } \\
\text { (Rs.) }\end{array}$ & $\begin{array}{l}\text { Per Head } \\
\text { (Rs.) }\end{array}$ & $\begin{array}{l}\text { Per Liter } \\
\text { (Rs.) }\end{array}$ & $\begin{array}{c}\text { Per Head } \\
\text { (Rs.) }\end{array}$ & $\begin{array}{c}\text { Per Liter } \\
\text { (Rs.) }\end{array}$ \\
\hline 1 & April & $\begin{array}{c}6.50 \\
(13.3) \\
12.36 @\end{array}$ & $\begin{array}{c}1.80 \\
11.83 @\end{array}$ & $\begin{array}{c}7.92 \\
(3.6) \\
15.06 @\end{array}$ & $\begin{array}{c}2.2 \\
15.22 @\end{array}$ & $\begin{array}{c}37.97 \\
(3.50) \\
72.21 @\end{array}$ & $\begin{array}{c}10.54 \\
72.95 @\end{array}$ & 52.39 & 14.54 \\
\hline 2 & May & $\begin{array}{c}6.69 \\
(13.38) \\
12.41 @\end{array}$ & $\begin{array}{c}1.71 \\
12.35 @\end{array}$ & $\begin{array}{c}8.14 \\
(3.7) \\
15.10 @\end{array}$ & $\begin{array}{c}2.09 \\
15.10 @\end{array}$ & $\begin{array}{c}39.06 \\
(3.60) \\
72.48 @\end{array}$ & $\begin{array}{c}10.04 \\
72.54 @\end{array}$ & 53.89 & 13.84 \\
\hline 3 & June & $\begin{array}{c}6.96 \\
(13.92) \\
12.35 @\end{array}$ & $\begin{array}{c}1.66 \\
11.84 @\end{array}$ & $\begin{array}{c}8.14 \\
(3.7) \\
14.45 @\end{array}$ & $\begin{array}{c}2.07 \\
14.77 @\end{array}$ & $\begin{array}{c}41.23 \\
(3.80) \\
73.19 @\end{array}$ & $\begin{array}{c}10.28 \\
73.37 @\end{array}$ & 56.33 & 14.01 \\
\hline 4 & July & $\begin{array}{c}6.80 \\
(13.6) \\
11.68 @\end{array}$ & $\begin{array}{c}1.56 \\
11.63 @\end{array}$ & $\begin{array}{c}8.03 \\
(3.65) \\
13.79 @\end{array}$ & $\begin{array}{c}1.85 \\
13.79 @\end{array}$ & $\begin{array}{c}43.4 \\
(4.0) \\
74.53 @\end{array}$ & $\begin{array}{c}10.00 \\
74.57 @\end{array}$ & 58.23 & 13.41 \\
\hline 5 & August & $\begin{array}{c}6.77 \\
(13.55) \\
11.12 @\end{array}$ & $\begin{array}{c}1.09 \\
11.07 @\end{array}$ & $\begin{array}{c}8.36 \\
(3.8) \\
13.74 @\end{array}$ & $\begin{array}{c}1.35 \\
13.71 @\end{array}$ & $\begin{array}{c}45.75 \\
(4.20) \\
75.14 @\end{array}$ & $\begin{array}{c}7.40 \\
75.20 @\end{array}$ & 60.88 & 9.84 \\
\hline 6 & September & $\begin{array}{c}6.72 \\
(13.44) \\
10.55 @\end{array}$ & $\begin{array}{c}1.28 \\
10.52 @\end{array}$ & $\begin{array}{c}8.14 \\
(3.7) \\
12.78 @\end{array}$ & $\begin{array}{c}1.55 \\
12.74 @\end{array}$ & $\begin{array}{c}48.82 \\
(4.5) \\
73.66 @\end{array}$ & $\begin{array}{c}9.33 \\
76.72 @\end{array}$ & 63.68 & 12.16 \\
\hline 7 & October & $\begin{array}{c}7.0 \\
(14.0) \\
10.83 @\end{array}$ & $\begin{array}{c}0.9 \\
10.82 @\end{array}$ & $\begin{array}{c}7.7 \\
(3.5) \\
12.98 @\end{array}$ & $\begin{array}{c}1.00 \\
11.87 @\end{array}$ & $\begin{array}{c}49.91 \\
(4.6) \\
77.24 @\end{array}$ & $\begin{array}{c}6.51 \\
77.31 @\end{array}$ & 64.61 & 8.42 \\
\hline 8 & November & $\begin{array}{c}7.01 \\
(14.02) \\
11.01 @\end{array}$ & $\begin{array}{c}0.78 \\
10.56 @\end{array}$ & $\begin{array}{c}7.81 \\
(3.55) \\
12.27 @\end{array}$ & $\begin{array}{c}1.14 \\
15.44 @\end{array}$ & $\begin{array}{c}48.82 \\
(5.0) \\
76.71 @\end{array}$ & $\begin{array}{c}5.46 \\
73.96 @\end{array}$ & 63.64 & 7.38 \\
\hline 9 & December & $\begin{array}{c}7.21 \\
(14.42) \\
9.60 @\end{array}$ & $\begin{array}{c}0.93 \\
10.41 @\end{array}$ & $\begin{array}{c}7.81 \\
(3.55) \\
11.27 @\end{array}$ & $\begin{array}{c}1.00 \\
11.19 @\end{array}$ & $\begin{array}{c}54.25 \\
(5.1) \\
78.31 @\end{array}$ & $\begin{array}{c}7.00 \\
78.38 @\end{array}$ & 69.27 & 8.93 \\
\hline 10 & January & $\begin{array}{c}7.23 \\
(14.46) \\
10.23 @\end{array}$ & $\begin{array}{c}0.78 \\
11.55 @\end{array}$ & $\begin{array}{c}8.03 \\
(3.65) \\
11.37 @\end{array}$ & $\begin{array}{c}0.86 \\
12.74 @\end{array}$ & $\begin{array}{c}55.36 \\
(5.2) \\
78.39 @\end{array}$ & $\begin{array}{c}5.97 \\
88.84 @\end{array}$ & 70.62 & 7.61 \\
\hline 11 & February & $\begin{array}{c}7.23 \\
(14.48) \\
10.08 @\end{array}$ & $\begin{array}{c}1.06 \\
11.26 @\end{array}$ & $\begin{array}{c}8.14 \\
(3.7) \\
11.33 @\end{array}$ & $\begin{array}{c}1.05 \\
11.15 @\end{array}$ & $\begin{array}{c}56.44 \\
(5.3) \\
78.56 @\end{array}$ & $\begin{array}{c}7.30 \\
77.57 @\end{array}$ & 71.8 & 9.41 \\
\hline 12 & March & $\begin{array}{c}7.25 \\
(14.5) \\
9.96 @\end{array}$ & $\begin{array}{c}1.10 \\
9.95 @\end{array}$ & $\begin{array}{c}8.03 \\
(3.65) \\
11.03 @\end{array}$ & $\begin{array}{c}1.22 \\
11.04 @\end{array}$ & $\begin{array}{c}57.50 \\
(5.3) \\
79.00 @\end{array}$ & $\begin{array}{c}8.73 \\
79.00 @\end{array}$ & 72.78 & 11.05 \\
\hline & Mean & Rs. 6.95 & Rs. 1.22 & Rs. 8.02 & Rs. 1.44 & Rs. 48.20 & Rs. 8.21 & Rs. 63.17 & Rs. 10.88 \\
\hline
\end{tabular}

Note: (i) @ - Indicate percentage from total cost

(ii) Figures in the parentheses show the quantity of feed in kilogram

The average milk yield at the dairy farm was found to be 6.26 liters/head/ day, whereas variations in different months which are given in (Table 3), which is vary from 3.60 to 9.26 liters. Anwar and Younas (2000) reported the similar milk production in their study. The relationship between the number of milch animals and total feed cost of animals worked out and a highly significant $(\mathrm{P}>0.05)$ positive relationship with a correlation co-efficient value $\left(\mathrm{r}=0.6285^{* *}\right)$. A highly significant $(\mathrm{P}>0.05)$ and positive correlation was observed between the number of milch animals and buffalo milk production $(\mathrm{r}=$ $0.6246^{* *}$ ) however, a positive but nonsignificant relationship was found in case of cattle milk production ( $\mathrm{r}=0.6649$ N.S.). Therefore, the cost of milk production was on higher side than the return from this dairy farm, because this dairy farm mainly meant 
for research and education purposes not as a commercial dairy farm (Fig. 2).

The results clearly shows that while selecting the animals and calculating the economic viability, it is mainly the productivity which plays a dominant role in a dairy farm and results of this study confirmed that the crossbred cows are more economical and efficient feed converters and better results may obtained if arrangement could be made for regular supply of green fodder and concentrates at the farms. The cost of milk production could be reduced substantially if feeding practices and management of dairy animals are on scientific lines.

\section{References}

Akturk, D., Bayramoglu, Z., Savran, F., and Tatldil, F. 2010. The factors affecting milk production and milk production cost. J. Faculty of Vet. Med., University of Caucasus. 16(2): 329-335.

FAO statistical year Book. 2012. Food and Agri. Organization, (3): 204.

Gupta, J.N., and Kumar, P. 1988. Resource use efficiency in milk production in Muzaffarnagar district of Uttar Pradesh. Asian J. Dairy Res., 7(4): 203-212.

Muhammad, Anwar and Muhammad, Younas. 2000. Cost of milk production in district toba tek singh, punjab, pakistan, Pak. J. Agri. Sci., 37: 3-4.

Singh, C.B., Patel, R.K., and Sharma, S.P. 1986. Economics of milk production on small holding. Indian Dairyman, 38(8): 394.

Pedro Alan Sainz-Sanchez, Felipe LopezGonzalez, Julieta Gertrudis EstradaFlores, Carlos Galdino Martinez-Garcia and Carlos Manuel Arriaga-Jordan. 2017. Effect of stocking rate and supplementation on performance of dairy cows grazing native grassland in small-scale systems in the highlands of central Mexico, Trop. Anim. Health Prod., 49:179-186.

Tatlidil, F.F., and Akturk, D. 2009. Comparative analysis of dairy cattlebreeding farms on member and nonmember of breeders' association. Agri. J., Medwell Online. 4(1): 36-40.

Tuna, Alemdar, Betul, Bahadir and M. Necat Oren. 2010. Cost and Return Analysis and Technical Efficiency of Small Scale Milk Production: A Case Study for Cukurova Region, Turkey J. Animal and Vet. Adv., 9: 844-847.

Turkyhlmaz, M.K., and Aral, S. 2002. Effeciency of resource usage in dairy herds Aydin province and their marketing and organizational problems. Kafkas Univ Vet. Med. J., 8(1): 41-48.

DAHD \& F. Annual report. 2011-12. Department of animal husbandry, dairying and fisheries, Ministry of Agriculture, Government of India, New Delhi, 2:.10.

Statistics. 2011-12. National Dairy Development Board Gujarat.

\section{How to cite this article:}

Mayank Dubey, Vivek Pratap Singh, R.K. Pandey and A.K. Chaubey. 2017. Economic Analysis of Feeding Management and Milk Production at the University Dairy Farm. Int.J.Curr.Microbiol.App.Sci. 6(2): 480-486. doi: http://dx.doi.org/10.20546/ijcmas.2017.602.054 